\title{
Chapter 19 \\ Commentary: Dike Relocation \\ from an Environmental Policy \\ Perspective
}

\author{
Martijn F. van Staveren
}

Dike relocation is receiving ample attention in the academic literature, and many detailed case studies have been published on the topic in recent years (Bates and Lund 2013; Eden and Tunstall 2006; Scrase and Sheate 2005; Suddeth 2011; van Staveren et al. 2014; Warner 2008). Germany, the Netherlands and the United Kingdom top the charts of dike relocation projects in Europe, while also many regional programmes, such as in the vast Danube delta area, provide additional examples. Outside Europe, notably in the United States, large stretches of levees (synonym to dikes or embankments) in the Sacramento-San Joaquin delta in California, as well as along the Mississippi and its tributaries, have been relocated to increase rivers' discharge capacities, to facilitate flooding on previously enclosed land, and to restore overall natural dynamics in the floodplain.

The dike relocation case in the River Landscape Elbe-Brandenburg biosphere reserve presents interesting and useful insights into the emergence and apparent popularity of dike relocation initiatives; a shared objective with the studies referred to above. A key driver in this particular case was the governmental effort to turn agricultural land into floodplain forest, with the objective to improve the ecological state of the floodplain. For a deeper understanding of this driver, we can learn from other studies: calls for environmental protection and environmental movements since the 1970s strongly influenced water policy, where eco-inspired minds advocated for new ways of integrated environmental management, including water and ecology (Disco 2002; Saeijs 2008). This was the conceptual foundation of various approaches to flood management, from Building with Nature (Waterman 2008) to, most recently, Nature-based solutions and Ecosystem-based Disaster Risk Reduction (Renaud et al. 2013).

Similar to other dike relocation projects, the Elbe-Brandenburg project clearly identifies the governmental authorities' argument that rivers need more space, in

M. F. van Staveren $(\bowtie)$

Environmental Policy Group, Department of Social Sciences, Wageningen University,

Wageningen, Netherlands

e-mail: martijn.vanstaveren@wur.nl

T. Hartmann et al. (eds.), Nature-Based Flood Risk Management on Private Land, https://doi.org/10.1007/978-3-030-23842-1_19 
order to facilitate natural dynamics (flooding, nature restoration) to freely take their course. But after detailed investigation, such projects often display tight forms of flood control. Cases in the Netherlands show that it is meticulously predicted and controlled when, where and how much flooding is allowed on reconnected floodplains (van Staveren et al. 2014). Vegetation growth in widened floodplains has to be kept within certain physical boundaries in order to avoid obstructing overland flood conveyance. Some authors have therefore stated that room for the river is a synonym for "room for the engineer" (Van Hemert 1999). A question that also applies in the case of the River Landscape Elbe-Brandenburg biosphere reserve is to which extent dike relocations can be genuinely labelled as NBS, and to which extent they are "camouflaged" varieties of hydrocratic flood control.

Furthermore, it is useful to make a distinction between dike relocation projects along rivers on one hand and in coastal zones on the other. The geographical setting, providing terms of reference for environmental dynamics, determines the spatial possibilities for dike relocations. Besides the obvious variations in water quality (fresh water in the riverine area, and brackish or saline water in the coastal zone) influencing what kind of nature could be restored, also water-related dynamics strongly differ. Water dynamics in riverine areas are strongly season-based, which usually means that winter seasons come with higher and peak discharges compared to drier summers. In the coastal zone, water dynamics are influenced by river flows but also by twice-daily tides, pushing saline water into the estuary. Bodies of literature on both types of dike relocation have emerged (Borsje et al. 2011; French 2006; Warner et al. 2013; Waterman 2008). Each present a different terminology and concepts, such as "managed coastal realignment" (French 2006) and "Space for the River" (Warner et al. 2013).

In scientific disciplinary terms, the Elbe-Brandenburg case touches on policy studies, governance issues and stakeholder participation. Stakeholder participation in water management is a well-studied topic (Warner et al. 2013), and a shift from government to governance is indeed a key driver for more inclusive stakeholder participation projects in water management. A key challenge for policy makers here is to find a right balance between the extent of stakeholder involvement, and making decisions that might negatively impact some of these actors. In the dike relocation case in the River Landscape Elbe-Brandenburg biosphere reserve, stakeholders were kept onboard by means of structural involvement, not only with paper plans but also via a series of funded projects.

From the perspective of policy research, many dike relocation studies, including the piece under scrutiny, share the observation that dike relocations no longer concern a single policy domain. Nature restoration and flood prevention initiatives are often encountered simultaneously, leading some authors to speak of "green-blue alliances" when it comes to pursuing policy implementation in river management. In the Netherlands in particular, dike modifications date back to calls for environmental protection and restoration in the 1970s; the time of growing environmental concerns and environmental movements. This went hand in hand with critique on governments pursuing large-scale infrastructure with potentially negative environmental impacts. A third policy domain, that of climate change adaptation, became 
intertwined with nature restoration and water management after extensive (near) flooding in the mid-1990s in Germany and the Netherlands presented an impetus to rethink river management policies over longer timescales (Van Heezik 2008). It is relevant to highlight, as the dike relocation case in the River Landscape ElbeBrandenburg biosphere reserve also brings forward, that flood control is a stronger aim than nature restoration. The fourth strongly related policy domain, agriculture, often gets the worst of it in the shape of loss of (privately owned) land.

It is important to be careful to interpret the popularity of dike relocations being representational for a policy transition, which usually implies a shift from one style of river management to a different one. This would be tempting, as dike relocations and river widening ("opening up") fully contrasts with the conventional approach ("closing off') (Van Staveren et al. 2017). Transitions are often presented as a shift from approach A to B, where B supersedes the former approach A. However, comparing the length or surface area of dike relocations and river widening, it often turns out that they are very limited compared to modifications done to the remaining dike system. Even more, in the Netherlands, a vast amount of $943 \mathrm{~km}$ of dikes will be strengthened predominantly by means of "traditional" techniques to increase height and install reinforcements by 2050 in order to meet more strict flood safety norms (Ministry of Infrastructure and Water Management 2019). As mentioned earlier, dike relocation projects carry with them strong notions of flood control. River restoration in the United States receives ample attention and substantial financial investment these days (The Nature Conservancy 2018). Although it is obvious that FRM policies have changed over the last decades, dike relocation initiatives can best be regarded as taking place on the fringes of dominant full flood prevention approaches in FRM. In policy studies vocabulary, they might be classified as niche developments (Geels and Schot 2007).

The key finding of the dike relocation case in the River Landscape ElbeBrandenburg biosphere reserve is that numerous actors with various perspectives have to be involved in decision making (Warner and Damm, this volume). This is certainly a challenge for policy implementers, who are often confronted with a large (local) stakeholder group, different opinions and various policy domains that have to be incorporated in final project designs. In that sense, dike relocations in areas with a high population density and intensive forms of land use have additional challenges. The implementation of the dike relocation case in the River Landscape Elbe-Brandenburg biosphere reserve benefited from that fact that it is a "remote region" with "the lowest population density in all of Germany" (Ministerium für Umwelt Gesundheit und Verbraucherschutz 2013) and a "difficult economic situation" against the background of the East-West divide and unification while substantial budgets were available from an external funder (Warner and Damm, this volume). These are important contextual factors in support of project acceptance and implementation. It is interesting to note that the authors argue that the earlier experience with a totalitarian state in the region would foster resistance to restoration efforts, rather than easy acceptance of state-driven projects (see on the topic also Scott 2008).

Finally, I relate their findings to the general objectives of the book on NBS. The authors underscore both challenges and stimulating factors related to dike reloca- 
tion projects as examples of NBS. Integrated thinking about river management can be seen as a no regret approach; whether projects are initiated from nature restoration or from a flood management perspective, integrated approaches stimulate the weaving together of policy domains in search of multifunctional interventions and win-win situations. On the other hand, it is also worthwhile to be realistic about the potential of dike relocations as examples of NBS. They can be suitable for some geographical settings, but will be more difficult to implement in areas with high population densities and intensive forms of land use.

Acknowledgements Open access of this chapter is funded by COST Action No. CA16209 Natural flood retention on private land, LAND4FLOOD (www.land4flood.eu), supported by COST (European Cooperation in Science and Technology).

\section{References}

Bates ME, Lund JR (2013) Delta subsidence reversal, levee failure, and aquatic habitat-a cautionary tale. San Francisco Estuary and Watershed Science. DIALOG. https://escholarship.org/ uc/item/9pp3n639

Borsje BW, van Wesenbeeck BK, Dekker F, Paalvast P, Bouma TJ, van Katwijk MM, de Vries MB (2011) How ecological engineering can serve in coastal protection. Ecol Eng 37(1):113-122. https://doi.org/10.1016/j.ecoleng.2010.11.027

Disco C (2002) Remaking "nature": the ecological turn in Dutch water management. Sci Technol Hum Values 27(2):206-235. https://doi.org/10.1177/016224390202700202

Eden SE, Tunstall S (2006) Ecological versus social restoration? how urban river restoration challenges but also fails to challenge the science-policy nexus in the United Kingdom. Environ Plann C Gov Policy 24(5):661-680. https://doi.org/10.1068/c0608j

French PW (2006) Managed realignment - the developing story of a comparatively new approach to soft engineering. Coast Shelf Sci Estuar 67(3):409-423. https://doi.org/10.1016/j.ecss.2005. 11.035

Geels FW, Schot JW (2007) Typology of sociotechnical transition pathways. Res Policy 36(3):399-417. https://doi.org/10.1016/j.respol.2007.01.003

Ministerium für Umwelt Gesundheit und Verbraucherschutz (2013) Elbe-Brandenburg river landscape biosphere reserve. https://www.elbe-brandenburg-biosphaerenreservat.de/fileadmin/user_ upload/PDF/LfU/Gebietsfaltblaetter_englisch/br_elbe_eng.pdf

Ministry of Infrastructure and Water Management (2019) Delta programme 2019. https:// english.deltacommissaris.nl/delta-programme/documents/publications/2018/09/18/dp2019-enprintversie

Renaud FG, Sudmeier-Rieux K, Estrella M (eds) (2013) The role of ecosystems in disaster risk reduction. United Nations University Press, Bonn

Saeijs HLF (2008) Turning the tide. Delft Academic Press, Delft, Essays on Dutch ways with water Scott JD (2008) Seeing like a state. Yale University Press, Yale

Scrase JI, Sheate WR (2005) Re-framing flood control in England and Wales. Environ Values 14(1)113-137. http://sro.sussex.ac.uk/26165/

Suddeth R (2011) Policy implications of permanently flooded Islands in the Sacramento-San Joaquin Delta. San Francisco Estuary Watershed Sci 9(2):1-18. http://doi.org/10.15447/sfews. 2011v9iss2art5

The Nature Conservancy (2018) New river plan will guide next decade of restoration along the Hudson. https://www.nature.org/en-us/explore/newsroom/new-river-plan-will-guidenext-decade-of-restoration-along-the-h/. Accessed 25 Nov 2018 
Van Heezik A (2008) Battle over the rivers. Two hundred years of river policy in the Netherlands, VHB and Rijkswaterstaat, Haarlem

Van Hemert M (1999) Ruimte voor de ingenieur. Rivierbeheer in Nederland eind jaren negentig. K\&M, Tijdschrift voor Empirische Filosofie 361-387

Van Staveren MF, Warner JF, Khan MSA (2017) Bringing in the tides. From closing down to opening up delta polders via Tidal River Management in the southwest delta of Bangladesh. Water Policy 19(1). http://doi.org/10.2166/wp.2016.029

van Staveren MF, Warner JF, van Tatenhove JPM, Wester P (2014) Let's bring in the floods: depoldering in the Netherlands as a strategy for long-term delta survival? Water Int 39(5). http:// doi.org/10.1080/02508060.2014.957510

Warner JF (2008) Emergency river storage in the Ooij polder-a bridge too far? Forms of participation in flood preparedness policy. Int J Water Resour Dev 24(4):567-582. https://doi.org/10. 1080/07900620801923153

Warner JF, Van Buuren A, Edelenbos J (2013) Making space for the river. Governance experiences with multifunctional river flood management in the US and Europe. IWA Publishing, London

Waterman RE (2008) Integrated coastal policy via building with nature. Dissertation, Delft University of Technology, Delft

Martijn van Staveren works at the Environmental Policy Group at Wageningen University. He completed his Ph.D., a comparative study on flood management policy in three different countries, in 2017 and continued as a postdoctoral researcher in a new research programme concerning the implementation of new flood safety norms in the Netherlands. His thematic focus is on the sociopolitical dimensions and knowledge co-development of flood risk management, with an interest in achieving long-term resilience to flooding and exploring the opportunities of ecosystem-based flood risk management.

Open Access This chapter is licensed under the terms of the Creative Commons Attribution 4.0 International License (http://creativecommons.org/licenses/by/4.0/), which permits use, sharing, adaptation, distribution and reproduction in any medium or format, as long as you give appropriate credit to the original author(s) and the source, provide a link to the Creative Commons license and indicate if changes were made.

The images or other third party material in this chapter are included in the chapter's Creative Commons license, unless indicated otherwise in a credit line to the material. If material is not included in the chapter's Creative Commons license and your intended use is not permitted by statutory regulation or exceeds the permitted use, you will need to obtain permission directly from the copyright holder.

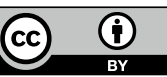

